\title{
Compreensões da origem e legislação do Deuteronômio
}

Understandings of the Origin and Legislation of

Deuteronomy

Pedro Kramer ${ }^{a}$

\section{Resumo}

O estado atual da questão sobre a pesquisa da origem e legislação do livro do Deuteronômio revela duas compreensões diametralmente opostas. Uma é representada pelos exegetas Norbert Lohfink e Georg Braulik e seus seguidores e a outra é defendida por Eckart Otto e seus discípulos. As divergências entre estas duas posições se manifestam principalmente a respeito da data de origem do Deuteronômio, da quantidade do seu conteúdo original, da adição de camadas literárias posteriores e do processo da sua formação. Neste momento não há nenhuma perspectiva de aproximação entre eles a curto prazo.

Palavras-chave: Deuteronômio. Camadas literárias. Legislação. Aliança. Centralização do culto.

\section{Abstract}

The current state of the question about the research of the origin and legislation of the book of Deuteronomy reveals two diametrically opposed understandings. One is represented by the exegetes Norbert Lohfink and Georg Braulik and his followers and the other is defended by Eckart Otto and his disciples. The divergences between these two positions are manifested mainly in regard to the date of the origin of the Deuteronomy, the quantity of its original content, the addition of later literary layers and the process of its formation. At the moment there is no prospect of rapprochement between them in the short term.

\footnotetext{
a Faculdade Palotina (FAPAS), Santa Maria, RS, Brasil. Doutor em exegese bíblica, e-mail: kramer_pedro@yahoo.com 
Keywords: Deuteronomy. Literary layers. Legislation. Alliance. Centralization of the cult.

\section{Introdução}

A apresentação do estado atual da questão sobre a origem e legislação do livro do Deuteronômio consiste em três passos. O primeiro quer levar o leitor e a leitora a conhecer melhor o livro do Deuteronômio como ele se encontra atualmente nas nossas Bíblias. Esta familiarização inicial com este livro é necessária porque este é, infelizmente, um dos livros da Bíblia mais desconhecidos. Isto é lamentável porque, segundo muitos pesquisadores, ele é o centro do Antigo Testamento. Este primeiro passo consiste da leitura sincrônica e canônica do texto deuteronômico.

O segundo passo se refere à leitura diacrônica do texto deste livro e revela compreensões diametralmente opostas, defendidas, por um lado, pelos exegetas Norbert Lohfink e Georg Braulik e seguidores e, por outro, por Eckart Otto e seus simpatizantes. Eles mesmos reconhecem que entre eles não há o mínimo de consenso. N. Lohfink chega até a afirmar que "em poucos livros da Bíblia a diferença de opinião é tão grande como no Deuteronômio, mesmo nos critérios que valem para a crítica literária e redacional” (1995, p. 19). Sua constatação é confirmada por G. Braulik (1986, p. 9-14) e por E. Otto (1999, p. 11).

Além destes dois grupos divergentes de biblistas, o exegeta Frank Cruesemann dedicou quase cem páginas ao estudo da origem e legislação do livro do Deuteronômio no seu livro Die Tora (1997, p. 235-322). Em vários pontos, ele diverge dos dois grupos de pesquisadores do Deuteronômio.

O terceiro passo exemplifica uma releitura que o próprio Moisés faz no seu terceiro discurso dos seus dois discursos anteriores, cujo tema é a violência e o extermínio de pessoas e povos em nome de lavé.

Conclusões e referências bibliográficas finalizam a tentativa de apresentar o status questionis da pesquisa atual deste livro tão importante da Bíblia. 


\section{Familiarização com o livro do Deuteronômio}

O livro do Deuteronômio parece ser um dos livros menos conhecidos do Antigo Testamento. Por isso, estas primeiras linhas visam à familiarização maior com este livro tão importante do Pentateuco e do Antigo Testamento, tratando de algumas questões bem básicas. A inspiração para realizar esta tarefa vem destes estudos: BRAULIK, 2019, p. 153-155; BRAULIK, 1986, p. 5-14 e VEIJOLA, 2004, p. 1-6.

O nome dado pelos judeus ao Deuteronômio é debarym, "palavras, discursos, fatos, acontecimentos". Quando traduzido do hebraico para o grego, recebeu o nome deuteronómion. Este termo é formado por duas palavras gregas, deuterós que significa "posterior, em segundo lugar" e nómos, "lei, orientação, norteamento". O vocábulo hebraico Torá, significa primeiramente "instrução básica, orientação fundamental e norteamento" e, apenas em segundo lugar, ele alude à "Lei”.

O termo deuteronómion aparece na Bíblia em língua grega, chamada Septuaginta, em Dt 17,18 e Js 8,32. Nestas passagens este vocábulo não tem o sentido de "segunda lei", mas de "cópia da lei", isto é, o "segundo exemplar da mesma lei" destinado ao uso do rei (Dt 17,14-20).

b) A leitura atenta do livro do Deuteronômio dá primeiramente a impressão de ser uma narração, porque descreve o itinerário dos israelitas, liderados por Moisés, desde o êxodo dos hebreus do Egito (Dt 4,20), passando pelo monte Horeb no deserto, até chegar ao lado leste do rio Jordão (Dt 1,1). Esta caminhada de quarenta anos até chegar às margens do Jordão, no dia 01/11/40, culminou com a ordem de lavé a Moisés para que ele neste dia subisse ao monte Nebo (Dt 32,48-52; 34,5-7), onde ele iria morrer. Aliás, a leitura do livro do Deuteronômio revela que Moisés é o autor de dois livros: o Deuteronômio que narra a história dos israelitas, liderados por ele, durante a caminhada de quarenta anos desde a saída do Egito até as margens do Jordão, e o livro da Torá, contendo o decálogo, Dt 5,6-21, e suas leis complementares, Dt 12-26, que ele inculcou nos israelitas em alguns lugares e 
depois a escreveu e a entregou aos cuidados dos levitas (Dt 31,9.24). A narração dos acontecimentos, mediados por Moisés desde a libertação do Egito até a terra prometida, encontra-se no Deuteronômio atual na forma de quatro discursos aos israelitas. Estes subdividem o livro em quatro partes, com títulos e conteúdos próprios.

O primeiro discurso, Dt 1,1-4,43, cujo título e conteúdo são designados pelo vocábulo debarym, "palabras": São estas as palavras que Moisés dirigiu a todo o Israel, no outro lado do Jordão (Dt 1,1). O segundo é intitulado pelo vocábulo torá, "Lei": Esta é a Lei que Moisés promulgou para os israelitas (Dt 4,44). Seu conteúdo básico são o decálogo e as leis complementares em Dt 4,44-28,68. O terceiro discurso tem como título o termo beryt, "aliança": São estas as palavras da aliança que lahweh mandara Moisés concluir com os israelitas na terra de Moab (Dt 28,69) e como conteúdo a realização da aliança entre lavé e os israelitas na terra de Moab (Dt 28,69-32,52). O quarto discurso é intitulado pelo termo beraká, 'bênção': Esta é a bênção que Moisés, homem de Deus, abençoou os israelitas, antes de morrer (Dt 33,1), cujo conteúdo são as bênçãos dirigidas às tribos de Israel em Dt 33,1-29. A partir do ponto de vista dos quatro discursos e de mais 22 falas menores de Moisés, o livro do Deuteronômio parece ser uma coleção de discursos e falas dele ao povo de Israel. Como estes discursos são todos proferidos por ele no dia da sua morte, eles dão a impressão de serem seus "discursos de despedida", ou melhor, seu "testamento" como anúncio definitivo da vontade de Deus para os israelitas. O estudioso J. L. Ska (2016, p. 208-212) não simpatiza muito com a definição do livro do Deuteronômio como "a narração do último dia de vida de Moisés", nem como um "arquivo" que recolhe fatos e ditos dele, nem como os "discursos de adeus". O autor prefere definir os discursos de despedida de Moisés "como um testamento que compromete publicamente o povo a permanecer fiel a seu Deus, particularmente à Lei de seu Deus e à aliança com seu Deus" (SKA, 2016, p. 210).

a) Detalhando cada um dos quatro discursos de Moisés, pode-se destacar no primeiro, Dt 1-3, a retrospectiva dele desde o êxodo libertador do Egito, a parada no monte Horeb e a caminhada até Moab, à leste do rio 
Jordão. Em Dt 4,1-40 ele exorta os israelitas a serem fiéis a lavé, seu único e exclusivo Deus, na terra prometida.

b) O longo discurso, Dt 5-28, pode ser dividido em duas partes. Na primeira, Dt 5-11, Moisés, o mediador da aliança entre lavé e o povo de Israel em base ao decálogo em Dt 5,6-21, insiste na veneração única e exclusiva de lavé. Na segunda parte, Dt 12,1-26,16, encontram-se as leis complementares do decálogo. Algumas séries delas só podem ser observadas no templo, o santuário central dos israelitas. Outras leis prescrevem o poder democratizado nos cargos de juiz, rei, sacerdote e profeta (Dt 16,18-18,22). A passagem Dt 26,17-19 contém o protocolo da realização da aliança. Em Dt 27 há uma coleção de leis para serem praticadas na terra prometida. E em Dt 28 há uma série de bênçãos e maldições para os casos da observância das leis ou não.

c) O terceiro discurso, Dt 29-32, trata primeiramente da realização da aliança em Moab. A seguir, Moisés fala da sua sucessão por Josué e o conclui com seu cântico. Seu quarto discurso se compõe da sua bênção às tribos de Israel (Dt 33; cf. Gn 49).

O segundo discurso de Moisés aos israelitas em Dt 5-28 é o mais longo de todos e o centro do Deuteronômio. Ele, com suas leis econômicas, sociais, cultuais, penais e civis, é bastante semelhante aos Códigos legais dos povos vizinhos de Israel, como o Código de Hamurabi. Para G. Braulik (2019, p. 155), este provavelmente influenciou o Código Deuteronômico, Dt 12-28. Isto se percebe nas suas três partes comuns:

CÓDIGO DE HAMURABI

1. Prólogo

2. Leis

3. Epílogo: bênção e maldição

\section{CÓDIGO DEUTERONÔMICO}

\author{
1. Prólogo: Dt 5-11 \\ 2. Corpo legal: Dt 12-26 \\ 3. Epílogo: bênção e maldição: Dt 28
}

a) Para este exegeta (2019, p. 155-156), o Código Deuteronômico, além disso, tem todas as características dos Códigos legais do Antigo Oriente 
Médio porque usa a linguagem e as expressões legais típicas como estas: Dt 4,45: São estes os testemunhos, os estatutos $e$ as normas que Moisés comunicou aos israelitas (cf. Dt 5,1; 6,1; 11,32; 12,1; 26,16; 28,1.13.15.45). Como os Códigos legais antigos, o Código Deuteronômico, Dt 12-26, se compõe de três blocos legais distintos. O primeiro, Dt 12,2-16,17, contém leis litúrgicas de centralização, cuja observância só pode acontecer no templo em Jerusalém, permeadas por leis sociais. O segundo bloco legal, Dt 16,18-18,22, se compõe de um esboço de Constituição para o povo de Israel, democratizando o poder entre juiz, rei, sacerdote e profeta. O terceiro bloco legal, Dt 19-25, é formado por leis que abrangem vários setores da sociedade israelita, isto é, um conjunto de leis do direito civil e penal.

b) Para G. Braulik (2019, p. 156), o Código Deuteronômico é, de fato, um Código legal porque suas leis nos três blocos legais seguem princípios e costumes legais típicos dos Códigos legais do Antigo Oriente. Isto se manifesta no conjunto de leis da centralização do culto única e exclusivamente no templo de Jerusalém (Dt 12,4-28), nas normas de fidelidade a lavé, o Deus único e exclusivo do povo de Israel (Dt 13,2-19), nas proibições de participar dos cultos a outros deuses (Dt 14,1-21), no tratamento das pessoas conforme seu estado de vida (Dt 22,13-19) e nas leis de celebração conforme a sequência dos tempos fortes: a comemoração da Páscoa e dos Pães Ázimos na primavera (Dt 16,1-8), a festa das Semanas (Dt 16,9-12) e a festa das Tendas no outono (Dt 16,13-15). Estes exemplos explicitam claramente que o livro do Deuteronômio contém um Código de leis muito semelhante aos Códigos legais dos povos vizinhos de Israel nos séculos VIII, VII e VI a.C.

c) O Código Deuteronômico, no entanto, não é só formalmente um Código legal, mas é, para ele (2019, p. 156), ao mesmo tempo, um texto que descreve a realização de um tratado ou de uma aliança entre lavé e o povo de Israel. Um tratado ou uma aliança é sempre uma ação bilateral. Na aliança entre lavé e os israelitas deve-se levar em conta a enorme diferença entre estes parceiros e de ambas as partes deve haver aceitação. Isto é explicitado no juramento de fidelidade ao conteúdo da aliança e nas consequências para 
os casos da observância ou não das suas cláusulas. Em vista disso, segue em Dt 28 uma série de bênçãos e maldições como recompensa pela fidelidade ou não aos compromissos assumidos por juramento na realização da aliança. G. Braulik é da opinião que o Código Deuteronômico, Dt 5-28, foi provavelmente influenciado pelos tratados hetitas de vassalagem entre um soberano e seus reis vassalos. Os elementos básicos dos tratados hetitas de vassalagem e do Código Deuteronômico não podem ser meros acasos:

TRATADO HETITA DE VASSALAGEM

1. Preâmbulo

2. Prólogo histórico

3. Declaração básica

4. Leis detalhadas

5. Lista de testemunhas divinas

6. Bênção e maldição

\section{CÓDIGO DEUTERONÔMICO}

1.

2. Prólogo histórico: Dt 5-11

3. Declaração básica

4. Leis detalhadas: Dt 12-26

5.

6. Bênção e maldição: Dt 28

O autor (2019, p. 157) explica que o elemento "preâmbulo" do tratado hetita está ausente no Código Deuteronômico porque nele são apresentados os parceiros que em cada Código são diferentes. E o elemento "testemunhas divinas" não se encontram no Código Deuteronômico por motivos óbvios, porque segundo este é a própria divindade lavé que faz aliança com seu povo. É uma surpresa geral como o esquema e os textos de tratado dos hetitas se conservaram na história, mesmo após a falência deste vasto império.

d) Além disso, G. Braulik (2019, p. 170-173) destaca que o Código Deuteronômico foi fortemente influenciado pelo texto do tratado de vassalagem do rei assírio Asaradão (680-669 a.C.) com seus reis vassalos, fazendo-os jurar fidelidade absoluta a seu filho e sucessor, o rei Assurbanipal (669-630 a.C.). A estilização do Código Deuteronômico como uma aliança entre lavé e o povo de Israel nos moldes do tratado assírio de vassalagem não é apenas formal, mas também de conteúdo porque alguns textos no Deuteronômio são transcrição literal de partes do texto do tratado assírio de vassalagem (Dt 13; 28). 


\section{Compreensões da origem e legislação do Deuteronômio}

A abordagem acima revelou que são complexas as formas e variados os conteúdos do livro do Deuteronômio, lido de modo sincrônico ou canônico como ele se encontra atualmente nas nossas Bíblias. A seguir, visa-se apresentar duas compreensões diametralmente opostas a respeito da sua origem e sua legislação. Uma compreensão é representada pelos pesquisadores G. Braulik (2019, p. 152-182) e N. Lohfink (1991, p. 15-24) e seus seguidores e a outra tem por base os estudos de E. Otto (1999). Há ainda a compreensão de F. Cruesemann (1997) que se concentra na Lei Deuteronômica, Dt 12-26, e não em todo o livro do Deuteronômio.

\section{Compreensão da origem e legislação do Deuteronômio segundo os exegetas G. Braulik e N. Lohfink}

a) Para estes exegetas (BRAULIK, 2019, p. 161-163; LOHFINK, 1991, p. 20-22) pode-se, pela primeira vez, falar da existência do Deuteronômio quando a "lei do altar" em Ex 20,24 foi reinterpretada e transformada nesta prescrição: toda a liturgia do povo de Israel deve ser realizada, daqui em diante, única e exclusivamente no templo de Jerusalém. Esta "lei do altar", que até agora permitia a realização do culto a lavé em qualquer lugar do território israelita: Far-me-ás um altar de pedra, e sobre ele sacrificarás os teus holocaustos e os teus sacrifícios de comunhão, as tuas ovelhas e os teus bois. Em todo lugar onde eu fizer relembrar a memória do meu nome, virei a ti e te abençoarei, foi transformada e centralizada única e exclusivamente no santuário central de Jerusalém. Em vista disso, de agora em diante, o decálogo cultual, Ex 34,10-26, foi transformado nas leis litúrgicas em Dt 12,216,17. Estas não podiam mais ser colocadas em prática em qualquer lugar do território israelita, mas única e exclusivamente no templo de Jerusalém. Sua fórmula de centralização soa mais ou menos como esta: Buscá-lo-eis somente Rev. Pistis Prax., Teol. Pastor., Curitiba, v. 11, n. 2, p. 275-310, maio/ago. 2019 
no lugar que lahweh vosso Deus houver escolhido, dentre todas as vossas tribos, para aí colocar seu nome e aí fazê-lo habitar (Dt 12,5)'. Além disso, os redatores originadores do Deuteronômio recorreram ao decálogo ético, um estágio anterior a Dt 5,6-21, e a algumas coleções de leis existentes desde longa data. Eles também releram narrações antigas relativas ao êxodo dos hebreus do Egito, aos acontecimentos no monte Horeb e à caminhada pelo deserto até a chegada à terra prometida e as atualizaram no Deuteronômio em formação. Eles igualmente recolheram oráculos dos profetas Amós, Oseias, Isaías e Miqueias. Todo este conteúdo foi relido numa época muito específica e deu origem à primeira fase do Deuteronômio, ao "Deuteronômio original", ao Urdeuteronomion.

b) A releitura dos conjuntos de textos acima mencionados aconteceu, para estes dois exegetas, num momento muito especial da história do povo de Israel: o governo do rei Ezequias (725-696 a.C.). No seu tempo a potência internacional era a Assíria. Para não ser pego de surpresa numa excursão militar dos reis assírios Salmanasar V (726-722 a. C.) e Sargão II (721-705 a.C.), o rei Ezequias pretendeu proteger a população rural do Reino do Sul obrigando-a a se refugiar nas cidades fortificadas. Esta ação, por melhor que fosse, teve consequências negativas. Uma delas era a separação das famílias das suas propriedades rurais e o corte do culto aos ancestrais. Ao lado desta ação bem intencionada do rei, ele também acolheu em Jerusalém um número considerável de israelitas do Reino do Norte que fugiram dos assírios quando invadiram seu território, destruindo suas cidades, matando muita gente e exilando um bom grupo de israelitas para o vasto reino da Assíria (2Rs 17,141). A arqueologia comprova o aumento da população israelita num bairro especial da cidade de Jerusalém.

Além disso, para G. Braulik (2019, p. 162) e para N. Lohfink (1991, p. 21), não se pode duvidar da historicidade da reforma religiosa de Ezequias, testemunhada em 2Rs 18,4: Foi ele que aboliu os lugares altos, quebrou as estelas, cortou o poste sagrado, e reduziu a pedaços a serpente de bronze que

\footnotetext{
1 No Deuteronômio atual, as seguintes leis têm como tema a centralização do culto no templo de Jerusalém: Dt 12,4-7.8-12.13-19.20-28; 14,22-27; 15,19-23; 16,1-8.9-12.13-15.16$17 ; 17,8-13 ; 18,1-8 ; 26,1-11 ; 31,9-13$.

Rev. Pistis Prax., Teol. Pastor., Curitiba, v. 11, n. 2, p. 275-310, maio/ago. 2019
} 
Moisés havia feito, pois os israelitas até então ofereciam-lhe incenso; chamavam-na Noestã. Nesta ação ele certamente também destruiu o altar de Betel no Reino do Norte, obrigando os refugiados nortistas a frequentar o templo de Jerusalém. E há ainda testemunhos arqueológicos que igualmente apontam para a centralização da liturgia em Jerusalém. O autor, por exemplo, menciona a inscrição de Hirbet Bet Layy (BLay 1), a 08 km à leste da cidade de Laquis: “JHWH (é) o Deus de toda a terra, os montes de Judá (pertencem) ao Deus de Jerusalém". Para este pesquisador, a inscrição afirma que "JHWH, o Deus Altíssimo, isto é, o Deus mundial, é, ao mesmo tempo, o Deus territorial de Judá, portanto, o Deus nacional com um novo título, o Deus da cidade de Jerusalém” (BRAULIK, 2019, p. 162). Ele ainda acrescenta esta observação: o título dado a lavé, “Deus de Jerusalém”, aparece apenas uma vez e se encontra em 2Cr 32,19: (Os servos de Senaquerib) falavam do Deus de Jerusalém como se ele fosse um dos deuses dos povos da terra, obra de mãos humanas. Esta passagem alude à campanha bélica de Senaquerib (704-681 a.C.) contra o rei Ezequias. Nesta mesma inscrição de Hirbet Bet Layy, lavé não é só o Deus mundial e o Deus de Jerusalém, mas ele é também o protetor da pessoa (BLay 3-4).

Em 2Rs 18,22 encontra-se uma pergunta retórica da delegação do rei Senaquerib ao rei Ezequias: Dir-me-eis talvez: É em lahweh, nosso Deus, que pomos a nossa confiança, mas não foi dele que Ezequias destruiu os lugares altos e os altares, dizendo ao povo de Judá e de Jerusalém: Só diante deste altar, em Jerusalém, é que deveis vos prostrar? Esta passagem parece se referir ao mesmo assunto que a arqueologia confirma: a destruição do templo de lavé em Tell Arad e o deslocamento do templo em Tell Sheba, nos quais não se prestou mais culto a lavé e nem foram mais utilizados para esta finalidade no século VII, mesmo durante o governo do idolátrico e assassino rei Manassés (696-642 a.C.). Todos estes testemunhos apontam para a centralização do culto no templo de Jerusalém no tempo do rei Ezequias (BRAULIK, 2019, p. 162).

Outro fato que contribuiu para a centralização da liturgia no santuário central em Jerusalém é a informação em 2Rs 18,13: No décimo quarto ano do 
rei Ezequias, Senqquerib, rei da Assíria, subiu contra todas as cidades de Judá e apoderou-se delas. Esta comunicação indica que o território de autonomia do rei Ezequias estava restrito apenas à cidade de Jerusalém porque o resto da região de Judá já tinha caído nas mãos dos assírios (BRAULIK, 2019, p. 162). O profeta Isaías deve igualmente se referir à redução do território de autonomia de Ezequias no seu oráculo: A filha de Sião foi deixada só como choça em vinha, como telheiro em pepinal, como cidade sitiada (Is 1,8-9). Todos estes testemunhos, portanto, correm, para esses dois exegetas, na mesma direção: eles apontam para a centralização de toda a liturgia no templo de Jerusalém durante o governo do rei Ezequias.

c) O rei Josias (640-609 a.C.) também realizou uma reforma religiosa, tanto no Reino do Sul como no Reino do Norte. Este era neste momento uma província assíria (2Rs 23,4-20). Para G. Braulik (2019, p. 162-163) e N. Lohfink (1991, p. 21-22) a reforma deste rei, seguindo o exemplo do rei Ezequias e dos reis anteriores Asa (1Rs 15,12-14), Josafá (1Rs 22,47) e Joás (2Rs 11,17-18), consistia na retirada do templo de Jerusalém de todos os elementos idolátricos e na destruição dos santuários sincretistas e idolátricos nos "lugares altos" de Judá e dos templos de Betel e Samaria. Sua ação antiidolátrica através da oferenda de sacrifícios e da celebração das festas religiosas no templo purificado de Jerusalém visava sobretudo reforçar a identidade própria do povo de Israel, seguidor do Deus lavé (Dt 6,4), e não protestar contra a dominação assíria. Porque seus reis estavam mais interessados na política econômica de submissão total e do pagamento em dia dos tributos.

Após a retirada de todos os símbolos e objetos da idolatria assíria, o rei Josias convocou todo o povo de Israel para renovar seu relacionamento com lavé (2Rs 23,1-3) no santuário central. A celebração da renovação da opção dos israelitas por lavé é bem especial. Porque esta renovação da aliança entre lavé e os israelitas acontece seguindo os moldes dos tratados dos reis assírios com seus reis vassalos. Um destes reis vassalos era o rei Manassés de Judá (696-642 a.C.), o qual provavelmente possuía uma cópia deste tratado. G. Braulik testemunha: "Josias interpretou em 622 a.C. a relação de Deus com Israel, apoiando-se principalmente nos juramentos assírios de lealdade, como Rev. Pistis Prax., Teol. Pastor., Curitiba, v. 11, n. 2, p. 275-310, maio/ago. 2019 
"aliança", isto é, como tratado e usou o Deuteronômio (de então) como base de um autocompromisso por juramento" (BRAULIK, 2019, p. 163).

Segundo estes tratados, os reis vassalos, em base a um texto contendo cláusulas, juravam fidelidade e lealdade ao grão-rei assírio. Os israelitas, no entanto, renovaram a aliança com lavé, jurando fidelidade a ele, através da obediência ao conteúdo do "livro da Torá ou da Lei" que foi encontrado no templo de Jerusalém e que o sumo sacerdote Helcias tinha entregado ao secretário de Estado Safã com estas palavras: Achei o livro da Lei no templo de lahweh (2Rs 22,11). Para G. Braulik (2019, p. 163) as passagens do texto 2 Rs 22,3-20; 23,1-3.21-23 são historicamente confiáveis e, talvez, ainda redigidas no tempo do rei Josias. Esta opinião é confirmada por N. Lohfink: "A apresentação do tempo de Josias em 2 Rs 22 s contém o texto de um documento que certamente já fora redigido no tempo de vida de Josias e que em suas declarações deve ser considerado confiável (2Rs 22,3-20; 23,1-3.2123)" (1991, p. 21-22). Portanto, este "livro da Lei", também chamado de "livro da Aliança", encontrado no templo, dá a impressão de ser um documento oficial e conhecido desde longa data. Este, como observa G. Braulik (2019, p. 163), não deve ser confundido com o Código da Aliança (Ex 20,22-23,33) porque nele não há prescrições de centralização dos sacrifícios e das festas no templo de Jerusalém. Por isso, o "livro da Lei"” só pode ser o "Deuteronômio original", redigido por redatores no tempo do rei Ezequias e que tinha caído no esquecimento no templo durante o tempo do rei idolátrico Manassés. Porém, agora, foi encontrado nele por ocasião das reformas e da purificação idolátrica.

O exegeta G. Braulik (2019, p. 164) imagina que o Deuteronômio original do tempo do rei Ezequias iniciava com a linda profissão de fé: Ouve, ó Israel: Iahweh nosso Deus é o único lahweh [...] (Dt 6,4-5; cf. 2Rs 23,3; 23,25). Ele continha textos exortativos relativos à observância das leis referentes ao culto e sanções de bênção e maldição. Neste "Deuteronômio original" não havia ainda leis sociais e nem a Constituição da democratização do poder em Dt 17,8-18,22. Este Ur-Deuteronomium era considerado a "Lei de lavé" (Dt 6,17; 28,45; 2Rs 22,19). Ele ainda não tinha sido proclamado por Moisés e 
nem possuía uma moldura narrativa para situá-lo historicamente. Ele era a base através da qual Josias e o povo de Israel renovaram seu relacionamento com lavé numa cerimônia de realização da aliança (2Rs 23,1-3; Dt 6,17). Esta renovação da aliança foi selada e ratificada através da celebração da páscoa: Celebrai a Páscoa em honra de lahweh, vosso Deus, do modo como está escrito neste Livro da Aliança (2Rs 23,21-23). O modo da celebração desta páscoa devia ser como aquela que está prescrita no "Deuteronômio original" em Dt 16,1-8. Esta páscoa era simplesmente inédita: Não se havia celebrado uma Páscoa semelhante a esta em Israel desde os dias dos Juízes. Ela foi comemorada no ano 622 a.C., no "décimo oitavo ano do governo do rei Josias' (2Rs 22,3).

A reforma religiosa de Josias e a renovação da aliança com a celebração da páscoa reavivaram nos israelitas o desejo de liberdade, de autonomia política e de reconquista do território do Reino do Norte, dominado pelos assírios. Isto, no entanto, se tornava possível porque a Assíria estava entrando em decadência. Este era o contexto histórico favorável, segundo os estudiosos N. Lohfink (1991, p. 125-142) e G. Braulik (2019, p. 164-165), para o surgimento da narração da conquista josiânica da terra (die joschijanische Landeseroberungserzaehlung) pelos redatores deuteronômicos. Esta encontra-se atualmente diluída em Dt 1 até Js 22. Ela foi redigida de tal modo para que pudesse servir de fundamentação política e de motivação religiosa para reconquistar o território do Reino do Norte, que estava em poder dos assírios, para assim refazer o território israelita conforme o tamanho que ele tinha nos tempos de Davi e Salomão.

d) O Deuteronômio original do tempo do rei Ezequias recebeu ainda outro acréscimo considerável no tempo do rei Josias, através do texto dos redatores deuteronômicos, narrando a conquista da terra prometida. A posse desta terra significava concretamente, neste momento histórico, a retomada do território do Reino do Norte sob o jugo dos assírios. Isto se tornava possível agora porque eles foram obrigados a se retirar deles. Assim tornavase novamente possível aos israelitas a retomada do território antigo, outrora pertencente às tribos israelitas. Esta narração foi de tal modo escrita para que pudesse servir de propaganda preparatória para a reocupação desse Rev. Pistis Prax., Teol. Pastor., Curitiba, v. 11, n. 2, p. 275-310, maio/ago. 2019 
território ocupado pelos assírios e para que desse continuidade ao movimento de restauração e de reforma nacional e cultual. O conteúdo da narração da ocupação da terra prometida foi descoberto pelos exegetas $\mathrm{N}$. Lohfink e G. Braulik e amplamente divulgado através de uma série de estudos deles (1982, p. 953-985) e (2019, p. 164) através da análise da sua terminologia, do uso dos mesmos verbos em várias séries de ação e do emprego das mesmas formas literárias em conjuntos de relatos maiores e menores. Esta narração, com suas características próprias, tinha em vista contar o que tinha acontecido outrora, antes e durante a conquista da terra de Canaã no século XIII a.C. e o que devia determinar a vida dos israelitas nela. Para alcançar esta finalidade, os narradores deuteronômicos retrocederam na história e relataram de tal modo os acontecimentos no monte Horeb, descritos em Dt 5 e 9-10, e criaram a Lei deuteronômica como Constituição social para que servissem à vida dos israelitas na terra prometida. Outro recurso utilizado por eles era a estilização do “Deuteronômio original” do ano de 622 a.C. num discurso feito por Moisés quando foi realizada a aliança em Moab, em continuidade com a aliança do monte Horeb.

e) A política expancionista do rei Josias, no entanto, como observa G. Braulik (2019, p. 165), tinha um concorrente muito poderoso na pessoa do faraó Psamético I (664-609 a.C.) que, de fato, se apoderou dos territórios assírios no oeste, pretendidos pelos israelitas. O faraó Necao II (609-594 a.C.) se encontrou com Josias em Meguido e o matou (609 a.C.). Com a morte do rei, acabaram todos os projetos de anexação dos territórios pertencentes no passado aos israelitas. Seus sucessores não continuaram sua política e seus projetos de reforma.

f) A situação dos israelitas começou a piorar dia após dia, até que em 587 a.C. o Reino de Judá caiu nas mãos do exército de Nabucodonosor (605562 a.C.), destruindo a cidade de Jerusalém e o templo e exilando para a Babilônia parte considerável da população do Reino do Sul. Dentro desta nova configuração histórica, o livro do Deuteronômio recebeu, segundo G. Braulik (2019, p. 165-166), novos enfoques. Os redatores deuteronômicos, 
chamados no exílio e depois dele, de deuteronomistas, concluíram que a catástrofe do exílio babilônico aconteceu por causa da infidelidade dos israelitas a lavé na opção pelos deuses e da desobediência às cláusulas da aliança (Dt 29,21-27; 6,18-19; 11,8.22-25).

Esta nova situação histórica provocou os redatores deuteronomistas que criaram textos como este: nova compreensão da aliança. Esta não é mais bilateral entre lavé e os israelitas nos moldes dos tratados assírios de vassalagem, mas unilateral, isto é, a aliança se torna condicionada apenas às promessas de Deus e não depende mais da obediência e da fidelidade dos israelitas às cláusulas da aliança. Esta forma de aliança foi jogada para o passado e está presente na aliança de lavé com Abraão e com os patriarcas, explicitada na promessa de terra e de descendência ( $G$ n 15,18; 17). Esta nova concepção de aliança se encontra, segundo G. Braulik (2019, p. 165), nos textos exílicos e pós-exílicos em Dt 4,1-40; 7-9; 29-30. Ela não depende mais da obediência às leis deuteronômicas (Dt 6,18-19; 11,8.22-25), mas das promessas de lavé a seu povo (Dt 4,31; 7,9; 9,5; 30,6). E, além disso, quando se retrocede na história para contemplar a caminhada dos hebreus no deserto, os temas agora destacados são os prodígios de Deus realizados neles. Estes são redigidos de tal forma para que pudessem servir de paradigma para a vida deles na terra prometida. Estes textos, é óbvio, só podem estar perpassados pelo reino da graça de Deus. Esta perspectiva e esta compreensão da aliança unilateral, baseadas na graça de Deus, possibilitam o retorno à pátria para recomeçar lá uma vida nova após o fim do exílio. A aliança unilateral, baseada na graça de Deus, é uma obra teológica gigantesca dos teólogos deuteronomistas.

g) Não somente esta temática foi adicionada ao "Deuteronômio original" pelos redatores deuteronomistas, mas, segundo G. Braulik (2019, p. 165), também o projeto da democratização do poder, partilhado entre juiz, rei, sacerdote e profeta (Dt 16,18-18,22). Na elaboração deste esboço de governo democrático, eles certamente foram influenciados pelas ideias presentes em 2Sm 8 e 12. Conforme G. Braulik (2019, p. 165), eles também criaram algumas coleções de leis como aquelas em Dt 15 e 19-25 para resolver as necessidades e os problemas dos judeus na terra prometida depois do exílio. Algumas delas Rev. Pistis Prax., Teol. Pastor., Curitiba, v. 11, n. 2, p. 275-310, maio/ago. 2019 
eram certamente muito antigas e já se encontravam no Código da Aliança e na Lei da Santidade (Lv 17-26). A adição destas coleções de leis e os outros acréscimos acima mencionados ao "Deuteronômio original”, fizeram surgir, para G. Braulik (2019, p. 166), o Código Deuteronômico (Dt 12-26) ou o "livro da Torá ou o livro da Lei”.

Sua sistematização e composição seguem a sequência dos mandamentos do decálogo em Dt 5,6-21. Estes são os princípios norteadores que devem ser concretizados, explicitados e atualizados nas leis complementares que agora formam três blocos: Dt 12,2-16,17; 16,18-18,22; 19,125,16. A tabela elaborada por G. Braulik (2019, p. 166) ajuda a compreender a correspondência e a relação entre os mandamentos do decálogo e as leis complementares:

\begin{tabular}{|c|c|c|c|}
\hline MANDAMENTOS & $\begin{array}{c}\text { LEIS } \\
\text { COMPLEMENTARES }\end{array}$ & MANDAMENTOS & LEIS COMPLEMENSTARES \\
\hline $\begin{array}{l}\text { Primeiro: } \text { Dt } \\
\text { 5, 6-10: } \\
\text { Proibição de adorar } \\
\text { deuses e fazer } \\
\text { imagem deles. }\end{array}$ & $\begin{array}{l}\text { Dt 12,2-13,19: Adorar } \\
\text { lavé, o Deus único, no } \\
\text { único templo. }\end{array}$ & $\begin{array}{l}\text { Quinto: Dt 5,17: Não } \\
\text { matarás. }\end{array}$ & $\begin{array}{l}\text { Dt 19-21: Preservar a vida. } \\
\text { Dt 22,1-12: Ponte entre } \\
\text { quinto e sexto mandamentos. }\end{array}$ \\
\hline $\begin{array}{l}\text { Segundo: Dt 5,11: } \\
\text { Proibição do uso em } \\
\text { vão do nome de } \\
\text { Deus. }\end{array}$ & $\begin{array}{l}\text { Dt 14,1-21: Vivenciar a } \\
\text { diferença ritual entre } \\
\text { israelitas e outros } \\
\text { povos. }\end{array}$ & $\begin{array}{l}\text { Sexto: Dt 5,18: Não } \\
\text { cometerás adultério. }\end{array}$ & $\begin{array}{l}\text { Dt 22,13-23,15: Proteger a } \\
\text { dignidade do varão e da } \\
\text { mulher. }\end{array}$ \\
\hline \multirow[t]{2}{*}{$\begin{array}{l}\text { Terceiro: Dt 5,12-15: } \\
\text { Guardarás o sábado. }\end{array}$} & $\begin{array}{l}\text { Dt 14,22-16,17: } \\
\text { Realizar a liturgia e a } \\
\text { fraternidade no ritmo } \\
\text { do tempo. }\end{array}$ & $\begin{array}{l}\text { Sétimo: Dt 5,19: Não } \\
\text { roubarás. }\end{array}$ & $\begin{array}{l}\text { Dt 23,16-24,7: Colocar as } \\
\text { necessidades e as relações } \\
\text { humanas acima do direito à } \\
\text { propriedade. }\end{array}$ \\
\hline & & $\begin{array}{l}\text { Oitavo: Dt 5,20: Não } \\
\text { testemunharás } \\
\text { falsamente contra o } \\
\text { teu próximo. }\end{array}$ & $\begin{array}{l}\text { Dt 24,8-25,4: Defender o } \\
\text { direito dos empobrecidos }\end{array}$ \\
\hline \multirow[t]{2}{*}{$\begin{array}{l}\text { Quarto: Dt 5,16: } \\
\text { Honrar pai e mãe. }\end{array}$} & $\begin{array}{l}\text { Dt } 16,18-18,22: \\
\text { Honrar as autoridades } \\
\text { em Israel. }\end{array}$ & $\begin{array}{l}\text { Nono: Dt 5,21a: Não } \\
\text { cobiçarás a mulher } \\
\text { do teu próximo. }\end{array}$ & $\begin{array}{l}\text { Dt 25,5-12: Defender a } \\
\text { descendência. }\end{array}$ \\
\hline & & $\begin{array}{l}\text { Décimo: Dt } 5,21 \mathrm{~b}: \\
\text { Não desejarás o } \\
\text { patrimônio do teu } \\
\text { próximo. }\end{array}$ & $\begin{array}{l}\text { Dt 25,13-16: Não usar peso e } \\
\text { medida falsos. }\end{array}$ \\
\hline
\end{tabular}


h) Todo este processo evolutivo da formação e composição do livro do Deuteronômio levou G. Braulik a afirmar que ele é "a resposta teológica à crise de identidade de Judá como sociedade de lavé" (BRAULIK, 2019, p. 169). Porque o Reino do Sul era no século VII a.C. um Estado vassalo dos assírios através da exploração econômica, do pagamento de tributos, da dependência política e da influência cultural e religiosa deles. Neste contexto, a fé no Deus lavé decresceu, manifestações religiosas e culturais ressurgiram e ligações às tradições do passado desbotaram. Justamente a este choque econômico, religioso e cultural dos assírios, o rei Josias respondeu com sua reforma religiosa, cultural e cultual, centralizando o culto no templo de Jerusalém e transformando o Deuteronômio num manual do direito de lavé. Para G. Braulik (2019, p. 169), os testemunhos arqueológicos demonstram o alto grau de alfabetização dos judeus neste tempo pré-exílico.

A grande questão era: como transformar a fé em lavé e a religião israelita para que se tornassem novamente transparentes e atrativas para os israelitas? Para G. Braulik (2019, p. 169), os redatores deuteronômicos e deuteronomistas conseguiram responder a este desafio gigantesco através da obra teológica e legal maravilhosa que é o Deuteronômio. Eles alcançaram seu objetivo quando releram as diferentes tradições passadas do povo de Israel e as sistematizaram para suas diversas situações no presente. Em vista disso, eles primeiramente criaram uma síntese da história da salvação através de resumos como o "credo histórico-salvífico" em Dt 26,5-10 e o "credo catequético" para a catequese familiar em Dt 6,20-25, apresentando lavé, o Deus único e exclusivo do povo de Israel. Eles, além disso, criaram uma sistematização ética através de um reduzido "decálogo ético", um estágio anterior ao decálogo atual em Dt 5,6-21, e uma linguagem própria como é típica a terminologia do Deuteronômio.

O livro do Deuteronômio, assim concebido, tornou-se o documento da própria identidade do povo de Israel e a declaração da independência da Assíria, porque agora este povo se relaciona com seu Deus na forma de aliança, com um ritual próprio da sua realização (Dt 26,16-19; 29,9-14) e com a leitura ritual de tempos em tempos para não esquecer o Código Rev. Pistis Prax., Teol. Pastor., Curitiba, v. 11, n. 2, p. 275-310, maio/ago. 2019 
Deuteronômico, sua Constituição e Carta Magna. Porque o que dava coesão e poder aos assírios eram os tratados que o rei e a população assíria faziam com seu deus central Assur ou com sua deusa Ichtar e os renovavam pública e solenemente através de juramentos de fidelidade e de lealdade. Esta ação deles foi agora assumida pelo povo de Israel e, por isso, eles também realizavam e renovavam a aliança com lavé, com autonomia própria e tendo por base um documento próprio: o Deuteronômio.

\section{Compreensão da origem e legislação do Deuteronômio segundo Eckart Otto}

Para este incansável pesquisador do livro do Deuteronômio, com suas numerosas publicações sintetizadas no seu livro (OTTO, 1999, p. 75) ${ }^{2}$, não se pode falar do "Deuteronômio original" a não ser referindo-se ao texto do compromisso de lealdade a lavé por juramento em 2Rs 22-23. Este texto, com formulação tardia, contém a base da reforma de Josias. Em vista disso, ele não aceita a opinião daqueles exegetas que consideram a origem do núcleo original do Deuteronômio no tempo do rei Ezequias ou no tempo exílico e pós-exílico. Para ele, portanto, o "Deuteronômio original", como centro da teologia e da literatura do Antigo Testamento, nasceu "com a ajuda de parto dos assírios para se voltar contra este parteiro desde a primeira insuflação de ar" (OTTO, 1999, p. 74). Em vista disso, os israelitas não juraram mais lealdade ao rei assírio e às suas divindades, mas declararam sua independência jurando lealdade apenas a lavé, seu único e exclusivo Deus (Dt 13; 17,2-7). Para este exegeta, "esta é a hora do nascimento da teologia da aliança no livro do Deuteronômio" (OTTO, 1999, p. 74).

Para E. Otto (1999, p. 364-378), a origem do livro do Deuteronômio e da sua legislação como um programa de renovação do povo de Israel através da centralização do culto no templo de Jerusalém, da ética de fraternidade e

\footnotetext{
2 Eckart Otto deve continuar defendendo suas teses referentes à origem e legislação do livro do Deuteronômio no seu comentário, pensado em quatro volumes, dos quais os primeiros já foram publicados: HThKAT. Freiburg: Herder, 2018.

Rev. Pistis Prax., Teol. Pastor., Curitiba, v. 11, n. 2, p. 275-310, maio/ago. 2019
} 
de irmandade e da integridade religiosa da sociedade israelita teve três redações distintas que foram se sucedendo e assim formando lentamente o Deuteronômio como ele se encontra hoje nas nossas Bíblias. O núcleo original e mais antigo do Deuteronômio tem por base grande parte do conteúdo do Código da Aliança, Ex 20,24-23,12 (OTTO, 1999, p. 217-364). Os redatores deuteronômicos o releram e o adaptaram à situação econômica, social, religiosa e familiar do século VII a.C. O "Deuteronômio original”, além disso, recebeu forte influência dos Códigos legais do antigo Oriente Médio, especialmente da tradição legal dos assírios (OTTO, 1999, p. 91-202). Quando nos juramentos de lealdade dos assírios se exigia fidelidade absoluta ao grãorei assírio, o Deuteronômio critica justamente esta exigência, subvertendo-a em Dt 13 e 28 num documento de juramento de fidelidade a lavé a quem única e exclusivamente se deve obediência.

a) A camada redacional mais antiga do Deuteronômio é, para o autor, tardiamente pré-exílica, do tempo do rei Josias, no Reino do Sul. Sua tese é esta:

O 'Deuteronômio original' (Urdeuteronomium) não é outro texto do que o compromisso de lealdade a lavé por juramento (2Rs 22-23). A origem do Deuteronômio, em forma de um 'Deuteronômio original', está tanto excluída para o tempo do rei Ezequias quanto para o tempo exílico ou até pós-exílico" (OTTO, 1999, p. 75; cf. p. 217).

A camada redacional mais antiga do Deuteronômio foi composta como um documento programático, visando renovar o culto e o direito, enfrentar o fenômeno da urbanização com suas várias consequências e reagir contra a dominação assíria através de um tratado de fidelidade única e exclusiva por juramento a lavé.

A grande inovação do Deuteronômio original é, para ele, a centralização do culto no santuário único e exclusivo de Jerusalém, explicitada nas leis em Dt 12 (OTTO, 1999, p. 341-351). Esta centralização vai afetar mais ou menos intensamente vários conjuntos legais que compõem o "Deuteronômio original": as leis em Dt 14,22-15,23; 26,2-13, o calendário das festas dos israelitas em Dt 16,1-17, o judiciário da sociedade israelita em Dt 16,18-18,8 e o conjunto de prescrições em Dt 19,2-25,12. Segundo este biblista, 
a centralização quer provar que "Jerusalém não está abaixo de Assur e que a religião de lavé não está abaixo da religião de Assur em racionalidade e modernidade" (OTTO, 1999, p. 365).

b) O Deuteronômio, como um programa de renovação do povo de Israel através da centralização do culto em Jerusalém, da ética de fraternidade e irmandade bem como da integridade religiosa da sociedade e do país no tempo do rei Josias, recebeu para E. Otto (1995, p. 99-104) duas releituras durante o exílio, com vários acréscimos e enfoques novos, transformando-o, assim, num projeto de Constituição para o novo povo de Israel após o exílio e depois de ter reocupado a terra de Canaã.

A primeira releitura da camada literária mais antiga do Deuteronômio foi feita por um redator, que E. Otto designa com a sigla $\operatorname{Dtr} \mathrm{H}$, isto é, o deuteronomista historiador no tempo do exílio (OTTO, 1995, p. 99-100). Seu centro integrador é a ideia do novo povo de Israel como "povo santo". O redator Dtr $\mathrm{H}$ destaca esta qualidade do povo de Israel em Dt 7,6 e a desenvolve em Dt 7,1-2.6.13-15; 20,1-20; 23,2-9; 21,10-14; 23,10-15. Deste redator Dtr H provêm também os textos Dt 12,8-12 e 25,17-19 porque eles igualmente enfatizam o rompimento total de Israel com os povos vizinhos em Dt 14,1-2.321a. Segundo este texto, Israel se abstém das práticas rituais proibidas nos v.1-2 e do consumo de carne dos animais impuros nos v.3-21a. Fazem parte ainda da camada redacional do Dtr $\mathrm{H}$ os capítulos Dt 1-3 e as introduções historiozantes às leis em Dt 12,29; 17,14; 18,9; 19,1; 26,1. Essa camada redacional visa destacar o povo de Israel como um "povo santo" na terra de Canaã e um decidido defensor da vida de inocentes e fracos. Seu redator deve ser situado em meio a círculos sacerdotais.

c) A segunda releitura da camada redacional mais antiga do Deuteronômio, com os acréscimos da camada redacional do $\operatorname{Dtr} \mathrm{H}$, foi elaborada também no exílio por um redator que E. Otto designa com a sigla Dtr $\mathrm{D}$, isto é, o deuteronomista do decálogo ou com a sigla Dtr N que significa o deuteronomista nomista (OTTO, 1995, p. 100-104). Este contribuiu na elaboração do projeto de Constituição para o novo povo de Israel, após o exílio e vivendo no seu país, quando transformou Dt 12-26 numa explicação e 
concretização do decálogo em Dt 5,6-21. Este texto é o núcleo fundamental enquanto que Dt 12-26 contém as leis complementares para preservar a liberdade alcançada. Para ele, pertence a esta camada redacional o texto Dt 16,20-17,1. Este cria a unidade que concatena toda a legislação referente à centralização do culto em Dt 12,1-17 com o conjunto literário Dt 17,2-25,17, cujo bloco maior é a lei da divisão dos poderes entre juiz, rei, sacerdote e profeta em Dt 17,2-18,22, e outras unidades menores que aparecem detalhadas no gráfico. Este ilustra a origem, formação e composição do livro do Deuteronômio:

\begin{tabular}{|c|c|c|}
\hline Deuteronômio original & Deuteronomista Histórico & Deuteronomista Nomista \\
\hline & Dt 1-3 & \\
\hline & & Dt 4,1-40 \\
\hline & & Dt 5,1.2-5.6-21.22-31.32.33 \\
\hline & & Dt 6,4-9.20-25 \\
\hline & Dt 7,1-2.6.8a.13-15.17-23 & Dt 7,5.9-11.12b \\
\hline & Dt 9,1-6 & Dt 9,7-29 \\
\hline & & Dt $10,1-22$ \\
\hline Dt $12,13-19.20-27$ & Dt 12,1 & Dt 12,2-4.29-31 \\
\hline $\begin{array}{l}\text { Dt 13,1-2a.3b.4a.6b.7.9-17. 18a } \\
.19\end{array}$ & & Dt 13,2b.3a.4b.5.6a.8.18b.19 \\
\hline Dt 14,22-27.28-29 & Dt 14,1-2.3-21a & \\
\hline Dt $15,1-2.7-10.11 b .12-18.19-23$ & & Dt $15,4-6$ \\
\hline Dt 16,1-16.16-17.18-19 & & Dt 16,20-17,1 \\
\hline Dt 17,2a.3a.4.5-7.8-10.12-13 & Dt 17,14 & Dt 17,2b.3a.5a.11.14-20 \\
\hline Dt $18,1.3-8$ & & Dt $18,9-22$ \\
\hline \multirow[t]{2}{*}{ Dt 19,2a.3b.4-6.10-13.15-21 } & Dt 19,2b.3a.7-8.9b.14 & Dt 19,1.9a \\
\hline & Dt $20,1-20$ & Dt 20,18 \\
\hline
\end{tabular}




\begin{tabular}{|l|l|l|}
\hline Dt 21,1-9.15-21 & Dt 21,10-14 & \\
\hline $\begin{array}{l}\text { Dt 22,1-7a.8-12.13-21a.22a.23. } \\
\text { 24a.25.26.27.28-29 }\end{array}$ & & Dt 22,7b \\
\hline Dt 23,2,3a.4a.8-9.16-26 & Dt 23,3b.4b.5-7.10-15 & \\
\hline Dt 24,1.4a.6-7.10-22 & Dt 24,5 & Dt 24,8-9 \\
\hline Dt 25,1-4.5-10.11-12 & Dt 25,17-19 & Dt 25,13-16 \\
\hline Dt 26,2.5a.10-13 & Dt 26,1 & Dt 26,1.3-4.5b-9.14.15.16-19 \\
\hline Dt 28,20-44 & & Dt 28,1-14 \\
\hline & & Dt 29,20.29 \\
\hline & Dt 31.1-6.7-8 & \\
\hline
\end{tabular}

Chama a atenção que este perito não tece nenhum comentário sobre Dt 8; 11; 27; 29-30; 32-34 e nem procura relacionar estes capítulos com uma ou outra camada literária que compõe o livro do Deuteronômio. Por que eles não cabem no seu modelo de compreensão da origem e legislação do livro do Deuteronômio? Algo semelhante pode ser dito a respeito de 2Rs 22-23. Para ele, a informação a respeito da conclusão da aliança de Josias e do povo de Israel com lavé em 2Rs 23,1-3 são de suma importância. Esta perícope é, para ele, o núcleo original e fundante do livro do Deuteronômio. Por que as outras informações em 2Rs 22-23 não são valorizadas? Aqui percebe-se, mais uma vez, quantas questões na pesquisa do Deuteronômio estão ainda abertas, urgindo explicações. E como entender os nexos entre os diversos conteúdos que compõem este livro?

\section{Compreensão da origem e legislação do Deuteronômio segundo Frank Cruesemann}

Este exegeta não é um pesquisador do livro do Deuteronômio como os estudiosos N. Lohfink, G. Braulik e E. Otto, que publicaram numerosos artigos sobre este livro. F. Cruesemann publicou um livro entitulado Die Tora (1997), 
traduzido para o português com o título A Torá (2002), no qual procura descrever sobretudo a relação do Código da Aliança (Ex 20,22-23,33) com o Deuteronômio, especialmente Dt 12-26, que ele chama de "Lei Deuteronômica". Esta é, para ele, a continuação do Código da Aliança, mas com uma série de aspectos novos. Ela foi relida, atualizada e concretizada para uma situação histórica nova, chegando até substituí-la (CRUESEMANN, 1997, p. 235-238).

Quando este biblista se pergunta a respeito da origem histórica da Lei Deuteronômica, Dt 12-26, ele primeiramente discorda daqueles exegetas que a consideram um produto da época exílica e pós-exílica (CRUESEMANN, 1997, p. 242-243) para defender categoricamente sua tese: "O Deuteronômio só é compreensível como um texto pré-exílico" (CRUESEMANN, 1997, p. 246). Ele recebeu uma nova codificação durante o governo do "povo da terra", "am há'aretz (2Rs 21,23-24), que matou o rei Amon (642 a.C.) e colocou Josias no trono do Reino de Judá, um menino de oito anos de idade. Para ele, portanto, "a origem da Lei Deuteronômica está relacionada com as circunstâncias do início do reinado de Josias" (CRUESEMANN, 1997, p. 248).

Para ele, o "povo da terra" é um grupo muito importante (CRUESEMANN, 1997, p. 248-251). É um grupo de agricultores proprietários de terra no Reino de Judá. É ele que determina a linha da economia, da política e da religião durante os trinta anos em que esteve no governo. Isto se verifica quando o rei Josias é morto em Meguido, porque é ele que indica seu filho Joacaz como sucessor (2Rs 23,30), preterindo seu filho Joaquim, dois anos mais velho (2Rs 23,31.36). Este depois se vingou do "povo da terra", obrigando-o a pagar altos tributos que eram canalizados para o Egito (2Rs 23,35).

Enquanto o "povo da terra" governava no Reino do Sul, a potência internacional era a Assíria. Os assírios dominavam em 701 a.C. todo o país de Israel, fora a cidade de Jerusalém. Esta situação determinou que a economia, a política, a religião e o culto dos israelitas fossem centralizados em Jerusalém e no seu templo. Esta cidade era o único espaço de autonomia no tempo do rei Ezequias (725-696 a.C.). Em vista disso, os redatores da Lei Deuteronômica centralizaram tudo em Jerusalém e no seu santuário. Isto 
transparece claramente nas leis em Dt 12 bem como em outras passagens. Em base a este pano de fundo histórico construído por F. Cruesemann, ele conclui: "No corpo propriamente dito da Lei Deuteronômica (Dt 12-26) não se pode contar com camadas exílicas amplas e importantes" (1997, p. 251).

Mesmo que o interesse deste pesquisador estivesse centrado em Dt 1226, ele observa que no livro do Deuteronômio trabalharam várias gerações. Por isso, os capítulos, Dt 1-3.4.29-30, são, para ele, textos que surgiram na época exílica e pós-exílica (CRUESEMANN, 1997, p. 239). São igualmente deste tempo do conjunto literário Dt 5-11, os capítulos Dt 5.9-10, e da Lei Deuteronômica, Dt 12-26, os capítulos Dt 16,18-18,22 que tratam da partilha do poder entre juiz, rei, sacerdote e profeta.

\section{Violência e extermínio no livro do Deuteronômio: Saberás hoje que lahweh teu Deus exterminará os enacim. Tu os farás perecer, conforme te falou lahweh teu Deus (Dt 9,3)}

Não é possível falar do Deuteronômio sem mencionar as passagens mais horríveis do Antigo Testamento que tratam da violência contra pessoas e povos e do seu extermínio total em nome de Deus. A estatística confirma esta constatação: os verbetes haram/herem, "exterminar/extermínio" são muito usados na literatura deuteronômica e deuteronomista, especialmente nos livros do Deuteronômio e de Josué. Quase a metade do seu emprego aparece nestes dois livros 3 .

\footnotetext{
${ }^{3}$ O verbo haram, no hifil, aparece em Dt 2,34; 3,6 (2x); 7,2; 13,16 (cidade israelita sacrificada como anátema); 20,17 . O substantivo herem é usado em Dt 7,26 (2x e é aplicado à imagem de deuses); 13,18 (cidade israelita sacrificada como anátema com seus bens). No livro de Josué estes dois verbetes aparecem em Js 2,10; 6,18.21; 8,26; 10,1.28.35.39.40; 11,11.12.20.21. 


\section{Violência e extermínio na guerra de conquista da terra prometida: Saberás hoje que lahweh teu Deus vai atravessar à tua frente como um fogo devorador (Dt 9,3)}

a) Sob este título visa-se entender porque a aplicação do "extermínio" total aparece com tanta frequência e com tamanha brutalidade e, além disso, ordenado pelo Deus lavé, nos livros do Deuteronômio (Dt 2-3; 7; 9) e de Josué (Js 6-11). Para poder compreender melhor a parte mais horrível da Bíblia, o exegeta N. Lohfink (1992, p. 40) observa que primeiramente deve-se partir do fato de que os livros do Deuteronômio e de Josué foram escritos nos séculos VII e VI a.C. E que foi apenas neste tempo que os redatores deuteronômicos e deuteronomistas relataram as guerras dos israelitas contra os povos cananeus por ocasião da conquista da terra prometida pelo ano 1.200 a.C., sob a liderança de Moisés e de Josué. Há, portanto, uma diferença de séculos entre o fato da conquista da terra prometida e a redação por escrito da sua ocupação. Outra premissa necessária deste biblista é a pergunta pelo valor histórico destes textos escritos meio milênio depois dos fatos acontecidos, tendo em mente que seus redatores não presenciaram tais guerras e nem dispunham de fontes históricas fidedignas. Sua terceira premissa se refere ao sentido e à finalidade dos redatores bíblicos ao colocar por escrito, após meio milênio de anos, o aniquilamento dos sete povos cananeus, levando em conta que eles já há vários séculos não existiam mais e que alguns deles talvez nunca tenham existido, a não ser através de contos lendários (Dt 7,1-5).

b) Se é verdade que os redatores deuteronômicos e deuteronomistas escreveram seus textos sobre as guerras de conquista da terra prometida pelo ano 1.200 a.C. no final dos séculos VII e VI a.C., então, deve-se perguntar qual era a situação histórica em que estes redatores e seus contemporâneos viviam. Sem entrar muito em detalhes, deve-se afirmar que a segunda parte do século VII a.C. estava marcada pelo governo do rei Josias (640-609 a.C.) de Judá. Nesta época a potência internacional era a Assíria, mas já em franca decadência. Em vista disso, os redatores deuteronômicos relataram as guerras de conquista da terra prometida sob a liderança de Moisés e de Josué de tal modo que pudessem servir de fundamentação teológica e de estímulo Rev. Pistis Prax., Teol. Pastor., Curitiba, v. 11, n. 2, p. 275-310, maio/ago. 2019 
para os soldados israelitas na reconquista do território do Reino do Norte que estava sob o poder do exército assírio desde o ano 722 a.C. E como os soldados assírios eram tremendamente cruéis no tratamento dos povos vencidos, por isso, também a guerra dos israelitas no passado contra os cananeus e agora contra os assírios é descrita com a mesma crueldade ou até maior ainda do que a dos assírios no seu modo de fazer guerra e de exterminar populações inteiras.

c) Neste contexto não se pode esquecer que as guerras eram normalmente feitas para ampliar o raio de ação da divindade do respectivo povo. Em vista disso, a guerra dos israelitas contra os assírios foi realizada em nome de lavé, a fim de ampliar o seu domínio. Para, então, destacar que o Deus lavé é mais forte e mais poderoso do que os deuses dos assírios, a vitória dos israelitas sobre eles foi relatada de modo muito mais estrondoso do que as vitórias dos assírios. E como estes muitas vezes aniquilavam nas guerras populações inteiras, assim também agora o exército israelita, em nome de lavé, vai exterminar brutalmente todos os seus inimigos. Este é o contexto histórico que subjaz à passagem: Quando lahweh teu Deus te houver introduzido na terra em que estás entrando para possuí-la, e expulsando nações mais numerosas do que tu - os gergeseus, os amorreus, os cananeus, os fereseus, os heveus e os jebuseus, - sete nações mais numerosas e poderosas do que tu; quando lahweh teu Deus entregá-las a ti, tu as derrotarás e as sacrificarás ao extermínio. Não farás aliança com elas e não as tratarás com piedade (Dt 7,1-2).

d) Mesmo situando os textos que falam da violência e do extermínio no seu devido contexto histórico, eles continuam escandalizando. E não há dúvida de que continua chocante a afirmação segundo a qual Deus manda aniquilar pessoas e populações inteiras de cidades e de nações. É quase incompreensível imaginar que um redator israelita pudesse ter escrito este texto: Saberás hoje que lahweh teu Deus vai atravessar à tua frente, como um fogo devorador, é ele quem os exterminará e é ele quem os submeterá a ti. Tu, então, os desalojarás e, rapidamente, os farás perecer, conforme te falou lahweh (Dt 9,3). N. Lohfink concluiu suas ideias a respeito da atribuição dos 
textos de violência e de extermínio aos redatores deuteronômicos e deuteronomistas nos séculos VII e VI a.C. afirmando: "Num certo sentido, Deus é e permanece um Deus da violência e do aniquilamento de todo o mal. Ele é isto, apesar de ser o Deus da paz e exige dos seus a renúncia à violência" (LOHFINK, 1995, p. 41).

\section{Não à violência e ao extermínio humano! Moisés relê seus discursos em Dt 29-30}

Quanto mais se estuda o livro do Deuteronômio, tanto mais cresce na pessoa a consciência de que, de fato, seu processo de formação durou aproximadamente trezentos anos. Nele há textos dos séculos VIII, VII e VI a.C. O texto recebeu adições e releituras atualizando textos mais antigos para épocas posteriores. Em vista disso, para G. Braulik (2001, p. 113-150), há textos no livro do Deuteronômio que claramente supõem o exílio e que contêm o sonho explícito do regresso dos israelitas exilados na Babilônia para a terra prometida. Estes dois temas se encontram, para ele, em Dt 29-30. Nestes capítulos, seu redator relê discursos de Moisés, feitos no passado, e os atualiza para o presente. Nesta releitura ele também pode corrigir certas opiniões, por exemplo, o problema teológico sério que é a violência e o extermínio de pessoas e de povos, ordenados pelo Deus lavé, numa linguagem chocante e escandalosa.

A perícope Dt 30,1-10 é, para ele, "o único texto do Deuteronômio que tematiza expressamente o retorno de Israel do exílio para a sua terra" (BRAULIK, 2001, p. 136). O contexto literário anterior desta perícope é Dt 29 que, com Dt 28,69, introduz o terceiro discurso de Moisés aos israelitas. Como Dt 29 forma uma unidade retórica com Dt 30,1-10, por isso, a atenção volta-se primeiramente para Dt 29. Este capítulo alerta para a possibilidade do exílio, se os israelitas não forem fiéis a lavé, o Deus da aliança, e aborda o tema da relação do povo de Israel com as nações vizinhas. A temática do exílio aparece claramente nesta passagem: lahweh os arrancou do próprio 
solo com ira, furor e grande indignação, e os atirou numa outra terra, como hoje se vê (Dt 29,27).

É gratificante perceber na leitura de Dt 29-30, que tem como assunto o exílio dos israelitas na Babilônia, o fim do desterro e a reconquista da terra prometida, como seu redator omite todas as referências à violência e ao extermínio de pessoas e de populações na conquista da terra prometida no tempo de Moisés e de Josué. Estas, no entanto, se encontram presentes no primeiro discurso de Moisés em Dt 1,1-4,43. É um verdadeiro alívio poder ler e constatar que o extermínio de pessoas e de populações residentes na terra de Canaã e toda a violência praticada pelos israelitas contra elas em Dt 1,14,43 são totalmente omitidos em Dt 29,1-8, especialmente nos vv.6-7. O Moisés do terceiro discurso em Dt 28,69-30,20, portanto, relê e corrige seu primeiro discurso em Dt 1,1-4,43. A sinopse entre Dt 1,1-4,43 e Dt 29,1-8, elaborada por G. Braulik (2001, p. 137-138), mostra com toda a clareza a omissão dos termos de "violência" e "extermínio de pessoas e de populações inteiras":

\begin{tabular}{|l|l|}
\hline Dt 1,1-4,43: Israel à leste do rio Jordão & $\begin{array}{l}\text { Dt 29,6-7: Releitura da luta com Seon de } \\
\text { Hesebon e Og de Basã, à leste do Jordão }\end{array}$ \\
\hline $\begin{array}{l}\text { 1,31b: por todo o caminho que } \\
\text { percorrestes até que chegásseis a este } \\
\text { lugar. }\end{array}$ & 6a: Viestes até a este lugar. \\
\hline $\begin{array}{l}\text { 2,32: Seon saiu ao nosso encontro, ele e } \\
\text { todo o seu exército para a batalha em } \\
\text { Jasa. }\end{array}$ & 6aiu Seon, rei de Hesebon. \\
\hline $\begin{array}{l}\text { 2,33b: Deus no-lo entregou e seu filho e } \\
\text { todo o seu povo }\end{array}$ & \\
\hline $\begin{array}{l}\text { 2,34a: e apossamo-nos de toda a cidade } \\
\text { naquele tempo e sacrificamos ao } \\
\text { extermínio toda a cidade, varões, } \\
\text { mulheres e crianças }\end{array}$ & \\
\hline 2,34b: não deixamos nenhum & \\
\hline
\end{tabular}

Rev. Pistis Prax., Teol. Pastor., Curitiba, v. 11, n. 2, p. 275-310, maio/ago. 2019 


\begin{tabular}{|c|c|}
\hline sobrevivente. & \\
\hline $\begin{array}{l}\text { 3,1b: E saiu Og, rei de Basã, ao nosso } \\
\text { encontro, ele e todo o seu povo para a } \\
\text { querra em Edrai. }\end{array}$ & $\begin{array}{l}\text { 6b: E saiu Og, rei de Basã, ao nosso } \\
\text { encontro } \\
\text { para a guerra. }\end{array}$ \\
\hline $\begin{array}{l}\text { 3,3b: E o combatemos até que nenhum } \\
\text { sobrevivente lhe restasse. }\end{array}$ & Eo combatemos. \\
\hline $\begin{array}{l}\text { 3,4a: E apossamo-nos de todas as suas } \\
\text { cidades naquele tempo }\end{array}$ & \\
\hline 3,6a: e as sacrificamos ao extermínio. & \\
\hline $\begin{array}{l}\text { 3,6b: e sacrificamos ao extermínio toda a } \\
\text { cidade, varões, mulheres e crianças }\end{array}$ & \\
\hline $\begin{array}{l}\text { 3,8a: e tomamos naquele tempo a terra } \\
\text { da mão dos dois reis amorreus }\end{array}$ & 7a: e tomamos a sua terra \\
\hline $\begin{array}{l}\text { 3,12a: e ocupamos esta terra naquele } \\
\text { tempo. }\end{array}$ & \\
\hline 3,12b: dei-a a Rúben e a Gad & $\begin{array}{l}\text { 7a: e a demos como herança a Rúben, a } \\
\text { Gad }\end{array}$ \\
\hline $\begin{array}{l}\text { 3,13a: e o resto de Galaad e todo o Basã, } \\
\text { o rei de Og e dei à meia tribo de } \\
\text { Manassés. }\end{array}$ & 7b: e à meia tribo de Manassés. \\
\hline
\end{tabular}

a) Esta sinopse entre Dt 1,1-4,43 e Dt 29,1-8 demonstra que quase todo o vocabulário de Dt 29,6-7 foi extraído de Dt 1,1-4,43, o primeiro discurso de Moisés. Mas, quão diferente é seu linguajar no seu terceiro discurso em Dt 28,69-32,52! Ele, no seu primeiro discurso, orienta os israelitas para a conquista dos reis amorreus, à leste do rio Jordão, e lhes aplica, em nome de lavé, o herem, isto é, o extermínio total de Seon e do seu povo, com estas palavras: lahweh nosso Deus no-lo entregou e nós o vencemos, com seus filhos e todo o seu povo. Apossamo-nos então de todas as suas cidades e sacrificamos cada uma delas como anátema: homens, mulheres e crianças, sem deixar nenhum sobrevivente (Dt 2,33-34). Ele, além disso, aplica o herem, ou seja, o massacre total a Og, rei de Basã, e a seu povo, relatando: lahweh nosso Deus 
entregou em nossa mão também Og, rei de Basã, juntamente com todo o seu povo. [...] Apossamo-nos então de todas as suas cidades. [...] Sacrificamo-las como anátema, como havíamos feito a Seon, rei de Hesebon, anatematizando cada cidade, homens, mulheres e crianças (Dt 3,3-6).

Moisés no seu terceiro discurso releu seu primeiro e, felizmente, percebeu seu grave problema teológico, que é a violência e o extermínio de pessoas e povos em nome de Deus, com um linguajar chocante e escandaloso. Em vista disso, ele omitiu em Dt 29,1-8 o relato da guerra de extermínio total dos reis amorreus, Seon e Og, e das suas populações por ordem explícita de Deus. Mas, se porventura, no fim do exílio dos israelitas na Babilônia e no seu regresso para a terra prometida for necessário guerrear para reconquistá-la, este combate não será de extermínio total das nações residentes nela e nem será uma guerra por ordem explícita de lavé e ele mesmo não será o guerreiro principal à frente do exército israelita (Dt 29,6-7). Todas as palavras horrorosas de violência e de extermínio em Dt 1,1-4,43 foram omitidas em Dt 29,1-8. Que releitura transformadora e libertadora!

Esta releitura, no entanto, pode fazer surgir um problema porque tanto o texto em Dt 1,1-4,43 como em Dt 29,1-8 é Palavra de Deus. Qual destes dois textos é a Palavra verdadeira e genuína dele? A resposta é esta: a Palavra de Deus relida e atualizada para outra época é sua Palavra normativa e definitiva. Como Moisés releu seu primeiro discurso em Dt 1,1-4,43 e o modificou sensivelmente no seu terceiro, atualizando-o para a época do fim do exílio dos israelitas na Babilônia, ele se tornou o exemplo de intérprete normativo da Palavra de Deus para outro tempo. Sua releitura de Dt 1,1-4,43 e sua aplicação teológica para outra época em Dt 29,1-8 são exemplo e guia de releitura e de aplicação de Dt 1,1-4,43 também para o nosso tempo. Em vista disso, ninguém mais pode legitimar pela Bíblia e em nome de Deus a violência e o massacre de pessoas e de populações inteiras de cidades e de nações como está relatado em Dt 1,1-4,43. Porque a Palavra de Deus, relida e mediada por Moisés no seu terceiro discurso em Dt 29,1-8, proíbe terminantemente todo e qualquer extermínio de seres humanos, mesmo que seja por ordem explícita de uma divindade (BRAULIK, 2001, p. 138). Porque toda e qualquer 
divindade que manda matar pessoas não é Deus verdadeiro, mas é um ídolo devorador de pessoas inocentes.

b) Moisés no seu terceiro discurso em Dt 29,9-14 igualmente introduziu mudanças significativas na classificação dos participantes da aliança entre lavé e os israelitas em Moab. Para que a cerimônia da sua realização tivesse um caráter juridicamente válido, os membros ativos e participantes dela deviam ser especificamente destacados. Em vista disso, os membros convocados por Moisés, para constituir, desta vez, a assembleia oficial do povo de Israel, contêm surpresas interessantes. Porque, além de mencionar os chefes das vossas tribos, os anciãos, os escribas e todos os homens de Israel, com vossas crianças e mulheres, Moisés no seu terceiro discurso incluiu, de modo inesperado, o estrangeiro que está no teu acampamento, desde o que corta a madeira até o que tira a água para ti (vv.9-10). Ora, o estrangeiro, o cortador de lenha e o puxador de água não são israelitas, mas fazem parte dos antigos povos cananeus. Moisés, ao inclúílos na assembleia oficial dos israelitas no seu terceiro discurso, não só amplia sensivelmente o grupo dos membros oficiais que concluíram a aliança com lavé em Moab, mas relê e corrige textos do seu segundo discurso em Dt 4,44-28,68. A comparação entre este discurso de Moisés e do seu em Dt 29,9-14 revela algumas diferenças.

Uma delas aparece em Dt 7,1-2 do segundo discurso de Moisés onde ele transmite aos israelitas esta ordem de lavé: Tu sacrificarás como anátema os heteus, os gergeseus, os amorreus, os cananeus, os fereseus, os heveus e os jebuseus. Não farás aliança com eles e não os tratarás com piedade (cf. Dt 20,17). Mas que mudança Moisés introduziu no seu terceiro discurso em Dt 29,9-14! Porque em Dt 7,1-2 a aliança entre lavé e o povo de Israel era um privilégio único e exclusivo dos israelitas. $\mathrm{Na}$ descrição da aliança entre lavé e os israelitas em Moab em Dt 29,9-14, no entanto, são mencionados, entre os parceiros oficiais da aliança com lavé, populações cananeias, residentes à oeste do rio Jordão. E, além disso, se estas populações cananeias realizaram junto com os israelitas a aliança com lavé, juridicamente válida, então, tanto para elas como para os israelitas, o Código Deuteronômico, isto é, o decálogo em Dt 5 e suas leis complementares em Dt 12-26, se tornaram a base e a 
orientação das suas vidas na relação com lavé. Porque Moisés, no seu terceiro discurso em Dt 31,12, convocou oficialmente toda a população israelita, com o estrangeiro, para ouvir o Código Deuteronômico, para aprender a temer a lavé e para colocá-lo em prática: Reúne o povo, os homens $e$ as mulheres, as crianças e o estrangeiro que está em tuas cidades, para que ouçam e aprendam a temer a lahweh vosso Deus, e cuidem de pôr em prática todas as palavras desta Lei (Dt 31,12; cf. Js 8,35; 9) (BRAULIK, 2001, p. 138-140).

c) Moisés, no seu terceiro discurso em Dt 29,15-20, adverte os israelitas diante da possível apostasia de lavé na opção pelas divindades dos outros povos. Esta decisão deles acarretaria o rompimento da aliança concluída com lavé em Moab (Dt 29,9-14). Ele, no entanto, ao mencionar os egípcios e outros povos, cujos deuses eram uma constante tentação para os israelitas (Dt 29,15-16), não falou deles de modo pejorativo e negativo e nem os considera inimigos dos israelitas. Ele, surpreendentemente, não adicionou ao termo "Egito" a expressão negativa "casa da escravidão" e nem declarou a guerra de extermínio total aos povos, no meio dos quais os israelitas passaram, como, por exemplo, aos reis amorreus, Seon e Og, à leste do rio Jordão. Estas guerras de aniquilamento completo de pessoas e povos são totalmente omitidas em Dt 29,15-20. Aliás, para G. Braulik, esta formulação: habitamos na terra do Egito, só aparece em Dt 29,15 e deste país se omite “qualquer conotação de inimizade e opressão” (2001, p. 140).

E, além disso, Moisés, na sua fala em Dt 29,16-17 como parte do seu terceiro discurso, é tão reservado, retraído e sóbrio quando aponta para os perigos que corre a fé dos israelitas em lavé. Estes perigos são as tentações das divindades dos outros povos. Esta sua fala aqui é tão diferente daquele seu linguajar horroroso e escandalizante em Dt 7,1-5.25-26. Em Dt 7,25-26 ele até ordena que as imagens dos deuses cananeus sejam queimadas e consideradas como coisa abominável: Considera-as como coisas imundas $e$ abomináveis, pois elas são anátema.

d) Moisés, no seu terceiro discurso em Dt 29,21-28, descreveu a mudança da relação dos outros povos com os israelitas após estes terem rompimento da aliança com lavé e provocado seu desterro para a Babilônia. 
Esta mudança em Dt 29,21-28 se percebe muito bem quando se compara esta perícope com o texto que descreve o relacionamento dos outros povos com os israelitas em Dt 4,26-28 e Dt 28. Estes dois textos fazem parte tanto do primeiro como do segundo discurso de Moisés e têm como tema a dispersão dos israelitas pelo mundo e sua permanência no exílio. Por isso, enquanto que em Dt 28,49-50 lavé fará vir uma "nação longínqua" para executar o castigo contra os israelitas: uma nação de rosto duro, que não respeita o ancião e não tem piedade do jovem, ele em Dt 29,21 apenas convocará um “estrangeiro de passagem, nokry, de uma terra longínqua" como testemunha qualificada e as "nações" surpresas apenas perguntam pela causa do exílio dos israelitas: $E$ todas as nações dirão: "Por que lahweh agiu deste modo com esta terra?" E responderão: "É porque abandonaram a Aliança que lahweh havia concluído com eles, quando os tirou da terra do Egito" (Dt 29,23-24).

E, além disso, a fala de Moisés em Dt 4,26 anuncia que o exílio dos israelitas na Babilônia traria um corte total deles com a terra prometida: sereis depressa e completamente exterminados da face da terra. Este anúncio do rompimento radical deles com sua pátria é totalmente omitido em Dt 29,2127. E nesta perícope também não há nenhuma alusão a respeito da diminuição do seu número durante o exílio como enfatiza Dt 4,27: lahweh vos dispersará entre os povos e restará de vós apenas um pequeno número, no meio das nações (cf. Dt 28,62.64). E, por fim, em Dt 29,21-27 não há nenhuma referência ao castigo dos israelitas porque, segundo se imaginava, eles seriam obrigados pelos povos a adorar forçosamente seus deuses, feitos de madeira e de pedra, como explicita Dt 4,28: Lá servireis a deuses feitos por mãos humanas, de madeira e de pedra, que não podem ver e ouvir, comer ou cheirar (cf. Dt 28,36.64).

Moisés, portanto, releu em Dt 29,21-27 o exílio dos israelitas na Babilônia e o compreendeu de modo muito diferente como ele mesmo o tinha descrito nos seus discursos anteriores. Ele, aliás, fala do exílio em Dt 29,27 de modo discreto, sóbrio e reservado, sem mencionar os horrores explicitados em Dt 4,26-28 e em Dt 28. Sua compreensão do exílio ele resumiu nestas simples palavras: lahweh os arrancou do próprio solo com ira, furor $e$ grande indignação, e os atirou numa outra terra (Dt 29,27). Ele conclui sua 
análise da relação dos outros povos com os israelitas no exílio babilônico assim: "A destruição, como ameaça a Israel por causa do rompimento da aliança, já foi amplamente reduzida numa passagem programática e os povos são totalmente inocentados pela existência de Israel na diáspora" (BRAULIK, 2001, p. 144).

e) A respeito da perícope Dt 30,1-10 o biblista G. Braulik (2001, p. 144149) observa que se trata do único texto no Deuteronômio que dedica-se explicitamente ao exílio dos israelitas na Babilônia. Este texto Dt 30,1-10 é literariamente a sequência de Dt 29,21-28 e, em termos de conteúdo, está relacionado com Dt 4,27-30 e Dt 28,62-68. A relação de Dt 28,62-68 com Dt 30,1-10 se percebe claramente porque as maldições elencadas em Dt 28,62-68 são transformadas em bênção em Dt 30,1-10. Esta perícope é, de fato, uma releitura de Dt 4,27-30 e de Dt 28,62-68 e descreve o êxodo da Babilônia e a nova ocupação da terra prometida de forma muito diferente dos dois textos anteriores. G. Braulik (2001, p. 147) destaca que o êxodo dos israelitas da Babilônia narrado em Dt 30,1-10 não tem nenhuma conotação bélica como tem o relato do êxodo deles do Egito. Este é comparado em Dt 4,20 com a imagem da "fornalha de ferro" e em Dt 4,34 ele aconteceu através de sete ações violentas e bélicas de lavé. No entanto, o êxodo dos israelitas da Babilônia, relatado em Dt 30,4-5, não contém nenhuma resistência violenta e nem se fala do emprego da força: Ainda que tivésseis sido expulsos para os confins do céu, de lá te reuniria lahweh teu Deus, e de lá te tomaria para te reintroduzir na terra que os teus pais possuíram, para que a possuas; ele te fará feliz e te multiplicará mais ainda que os teus pais.

Se o êxodo da Babilônia é tão diferente da saída dos israelitas do Egito, então pode-se também supor que o relato do retorno da Babilônia e da reocupação da terra prometida seja diferente. De fato, a reintrodução de Israel na terra prometida narrada em Dt 30,5 se deu sem a guerra de extermínio total das nações. Esta reocupação da pátria querida não aconteceu através do aniquilamento delas como aquele aplicado outrora aos povos residentes em Canaã, segundo o testemunho em Dt 7,1-5 e Dt 9,3-4, 
mas será uma reunião feliz de todos os israelitas na terra prometida dos mais variados cantos da terra, onde se multiplicarão pacificamente.

\section{Conclusões}

O estudo do livro do Deuteronômio, mesmo que até agora não haja um consenso entre seus pesquisadores, revela que este é, de fato, o centro do Pentateuco e do Antigo Testamento. Seus criadores retrocederam na história e releram as tradições do passado para dar origem ao seu núcleo mais antigo numa situação histórica muito especial. Este "Deuteronômio original” foi relido e se encontra nas suas diversas camadas literárias, que foram se sucedendo de acordo com as mudanças históricas sofridas pelos israelitas.

O estado atual da pesquisa do livro do Deuteronômio manifesta que não haverá um consenso entre os estudiosos deste livro para curto prazo. 0 que está acontecendo neste momento são as investigações dos respectivos exegetas para fundamentar melhor e reforçar mais suas teses divergentes. Isto é altamente positivo porque assim crescem sensivelmente as descobertas do conteúdo deste livro.

\section{Referências}

BRAULIK, G. Deuteronomium 1-16,17. Die Neue Echter Bibel 15. Wuerzburg: Echter Verlag, 1986.

BRAULIK, G. "Die Voelkervernichtung und die Rueckkehr Israels ins Verheissungsland". Em: IDEM. Studien zum Deuteronomium und seiner Nachgeschichte. SBAB 33. Stuttgart: Verlag Katholisches Bibelwerk. 2001. p. 113-150.

BRAULIK, G. “Das Buch Deuteronomium”. Em: ZENGER et al. Einleitung in das Alte Testament. 9. ed. Stuttgart: Verlag W. Kohlhammer, 2019. p. 152-182.

CRUESEMANN, F. Die Tora. Theologie und Sozialgeschichte des alttestamentlichen Gesetzes. Guetersloh: Chr. Kaiser / Guetersloher Verlagshaus, 1997. Em português: CRUESEMANN, F. A Torá: Teologia e história social da lei do Antigo Testamento. Petrópolis: Vozes, 2002. 
LOHFINK, N. "Das Deuteronomium". Em: IDEM. Studien zum Deuteronomium und zur deuteronomistischen Literatur II. SBAB 12. Stuttgart: Verlag Katholisches Bibelwerk, 1991. p. 15-24.

LOHFINK, Norbert. "Deuteronomium und Pentateuch. Zum Stand der Forschung". Em: IDEM. Studien zum Deuteronomium und zur deuteronomistischen Literatur III. SBAB 20. Stuttgart: Verlag Katholisches Bibelwerk, 1995. p. 13-38.

LOHFINK, Norbert. "Der 'heilige Krieg' und der 'Bann' in der Bibel". Internationale Katholische Zeitschrift Communio 18 (1989) 104-112. In: Georg Braulik. Materialien zur Fundamentalexegese des Alten Testaments (Org.). Wien:1997. 3341 (Manuscrito).

LOHFINK, N. "Kerygmata des deuteronomistischen Geschichtswerks". Em: IDEM. Studien zum Deuteronomium und zur deuteronomistischen Literatur II. SBAB 12. Stuttgart: Verlag Katholisches Bibelwerk, 1991. p. 125-142.

OTTO, E. Das Deuteronomium. Politische Theologie und Rechtsreform in Juda und Assyrien. Berlin / New York: Walter de Gruyter, 1999.

KRAMER, P. Origem e Legislação do Deuteronômio. Programa de uma sociedade sem empobrecidos e excluídos. São Paulo: Paulinas, 2006.

SKA, J-L. O Canteiro do Pentateuco. Problemas de composição e de interpretação. Aspectos literários e teológicos. São Paulo: Paulinas, 2016.

VEIJOLA, T. Das 5. Buch Mose - Deuteronomium. Kapitel 1,1-16,17. Goettingen: Vandenhoeck \& Ruprecht, 2004. 